\title{
Xenorhabdus bovienii T228 phase variation and virulence are independent of RecA function
}

\author{
Rebecca A. Pinyon, Fan Hing Hew and Connor J. Thomas \\ Author for correspondence: Connor J. Thomas. Tel: +61 88303 5396. Fax: +618 83034362. \\ e-mail: connor.thomas@adelaide.edu.au
}

Microbiology and Immunology, Department of Molecular Biosciences, Adelaide University, Adelaide, South Australia 5005

\begin{abstract}
Colony pleomorphism, or phase variation, expressed by entomopathogenic bacteria belonging to the genus Xenorhabdus, is an important factor which determines the association of the bacteria with their nematode symbiont and the outcome of infection of susceptible insect larvae by the bacteriumnematode parasitic complex. The mechanism underlying phase variation is unknown. To determine whether RecA-mediated processes are linked to phase variation, the recA gene of Xenorhabdus bovienii was cloned and sequenced. When expressed in a recA-deleted strain of Escherichia coli, the $X$. bovienii recA clone was able to complement the loss of RecA function. $X$. bovienii chromosomal recA insertion mutants showed increased sensitivity to UV. Phase 1 forms did not show altered ability to convert to phase 2 and no significant differences in expression of other phase-dependent characteristics, including phospholipase $\mathrm{C}$, haemolysin, protease, antibiotic activity and Congo Red binding, were noted. Furthermore, the $\mathrm{LD}_{50}$ of the $X$. bovienii recA insertion mutant for Galleria mellonella larvae was not significantly different from that of wild-type strains. From these data the authors conclude that recA is unlikely to be involved in phase variation, the expression of phasedependent characteristics, or virulence factors involved in killing of susceptible larvae.
\end{abstract}

Keywords: entomopathogen, recombination, recA mutation, Galleria, phylogeny

\section{INTRODUCTION}

Xenorhabdus spp. are entomopathogenic bacteria symbiotically associated with insect-pathogenic nematodes belonging to the family Steinernematidae (Akhurst, 1993; Akhurst \& Dunphy, 1993; Forst \& Nealson, 1996). These bacteria are carried monoxenically within the foregut of non-feeding infectivestage nematodes. Nematodes invade the haemocoel of susceptible insect larvae and release bacteria into the haemolymph. Growth of the bacteria leads to a fatal septicaemia and creation of nutrient conditions necessary for host nematode reproduction within the insect (Akhurst, 1982b; Poinar \& Thomas, 1966). This process is aided by secretion of antibiotic substances which restrict the growth of other micro-organisms (Akhurst, 1982a).

Abbreviations: Ap, ampicillin; Km, kanamycin; NA, nutrient agar; NB, nutrient broth; $\mathrm{P} 1$, phase $1 ; \mathrm{P2}$, phase $2 ; \mathrm{Sm}$, streptomycin; $\mathrm{Tc}$, tetracycline. The GenBank accession number for the sequence reported in this paper is U87924.
Xenorhabdus spp. exhibit two colony forms, or variants, when cultured in vitro. Colonies of phase 1 (P1) variants are readily distinguished from those of phase 2 (P2) by the differential adsorption of dyes incorporated into the growth medium. Furthermore, P1 variants produce a range of extracellular products, including protease, lipase, phospholipase $\mathrm{C}$, haemolysin, antibiotic substances and Congo Red binding proteins (Akhurst, 1982a ; Boemare \& Akhurst, 1988; Akhurst \& Boemare, 1990; Nealson et al., 1990). Cytoplasmic inclusion bodies composed of highly crystalline proteins are produced during stationary phase (Couche \& Gregson, 1987; Couche et al., 1987). P2 forms are unable to (or only weakly) express many of these putative virulence determinants (Akhurst \& Boemare, 1990). However, the role of these determinants in the process of infection is unclear, since susceptible insect larvae are killed equally well by P1 and P2 forms of Xenorhabdus spp. Nevertheless, production of antibiotic substances by P1 forms prevents putrefaction of the cadaver by other microorganisms, and this helps support an environment conducive to nematode growth and reproduction. 
P1 cultures readily convert to P2 during extended liquid subculture and during the process of infection of insect larvae (Akhurst \& Boemare, 1990). The mechanism responsible for this pleomorphism is not yet understood. In some other bacteria, differential expression of virulence determinants and the process of phase variation are dependent on expression of functional RecA protein (Koomey et al., 1987; Ball et al., 1990; Zagaglia et al., 1991). To determine the role of RecA in phase variation in Xenorhabdus spp., we cloned and characterized the recA gene of Xenorhabdus bovienii T228. The ability of P1 wild-type and recA insertion mutants to convert to P2 forms was then compared. To eliminate the possibility that RecA may independently affect virulence of these bacteria for larvae, we also examined the ability of recA insertion mutants to infect and kill susceptible larvae.

\section{METHODS}

Bacterial strains and plasmids. The bacterial strains and plasmids used in this study are described in Table 1 . Unless otherwise specified, the P1 form of X. bovienii T228 was used in all experiments.

Growth media for bacterial cultures. All strains were stored in $15 \%(\mathrm{v} / \mathrm{v})$ glycerol and $1 \%(\mathrm{v} / \mathrm{v})$ peptone at $-70^{\circ} \mathrm{C}$. Fresh cultures of the P1 and P2 forms of Xenorhabdus bovienii were prepared by streaking a loopful of glycerol stock for single colonies onto a Nutrient Agar (NA) (Oxoid) plate and incubating for $36 \mathrm{~h}$ at $28^{\circ} \mathrm{C}$ prior to use. Escherichia coli and Sarcina lutea strains were plated on NA and incubated overnight at $37^{\circ} \mathrm{C}$. MacConkey agar no. 3 was purchased from Oxoid. Phase variants of X. bovienii T228 were confirmed by growth on BTB agar [NA $+0.0025 \%(\mathrm{v} / \mathrm{v})$ bromothymol blue and $0.004 \%(\mathrm{v} / \mathrm{v})$ tetrazolium chloride]. Where appropriate, antibiotics were added to broth and solid media at the following final concentrations: $100 \mu \mathrm{g}$ ampicillin $\mathrm{ml}^{-1}(\mathrm{Ap}), 50 \mu \mathrm{g}$ kanamycin $\mathrm{ml}^{-1}(\mathrm{Km}), 100 \mu \mathrm{g}$ streptomycin $\mathrm{ml}^{-1}(\mathrm{Sm}), 5 \mu \mathrm{g}$ tetracycline $\mathrm{ml}^{-1}(\mathrm{Tc})$.

Media required for identification of expression of phospholipase $\mathrm{C}$, haemolysin, protease and antibiotic activity were prepared using the standard techniques for Xenorhabdus spp. (Boemare et al., 1997). Congo Red NA was prepared by addition of Congo Red dye (Sigma) to NA at a final concentration of $0 \cdot 1 \%(\mathrm{v} / \mathrm{v})$.

Chemicals, reagents and enzymes. Chemicals were Analar grade. Unless otherwise stated, all chemicals in this study were purchased from Ajax Chemicals, BDH Laboratory Supplies or Sigma. Lysozyme was obtained from Sigma. Proteinase K and T4 ligase were purchased from Boehringer Mannheim. Restriction enzymes were routinely purchased from Boehringer Mannheim, New England Biolabs, Pharmacia Biotech or Progen Industries.

Isolation of DNA. Plasmid DNA was prepared using a standard three-step procedure (Maniatis et al., 1982). Chromosomal DNA was isolated by modification of a previously described method (Manning et al., 1986). Sequencing-grade plasmid DNA was prepared using QIAGEN columns following protocols described by the manufacturer.

DNA manipulations. PCR products and DNA fragments used for subcloning or preparation of DNA hybridization probes were purified either by phenol extraction (Bewsey et al., 1991), or using the Bresaclean DNA extraction kit (Bresatec). After restriction endonuclease digestion, enzymes were inactivated with heat and/or phenol/chloroform extraction. This was followed by precipitation with 2 vols $100 \%$ ethanol, and a $70 \%(\mathrm{v} / \mathrm{v})$ ethanol wash, before resuspension in an appropriate volume of purified water.

DNA sequencing and sequence analysis. DNA sequencing using dye-labelled primers and/or terminators was carried out using the PRISM Ready Reaction Cycle Sequencing Kit (Applied Biosystems). Searches for similarity to known DNA and protein sequences in databases were performed using the BLAST2 search service at EMBL (Altschul et al., 1990). Similar DNA and amino acid sequences were aligned using CLUSTALW (Thompson et al., 1994). The PHYLIP package (J. Felsenstein, University of Washington, USA) was used to determine the phylogenetic relationships of selected RecA amino acid sequences. Distance measures were obtained using the PROTDIST (Dayhoff PAM matrix) program. KITSCH was then used to estimate phylogenetic relatedness by a FitchMargoliash and least-squares method. КITSCH was configured to search for the best tree and randomize the input order of the sequences; a power setting of 2 was used. An unrooted phylogenetic tree was constructed using DRAWTREE.

Cloning and amplification of the $X$. bovienii recA gene. Preliminary sequence data were obtained through a strategy consisting of amplification of an internal recA fragment with the aid of degenerate oligonucleotide primers, followed by extension of the sequence data using a combination of inverse PCR and plasmid-assisted PCR rescue. These data were then used to amplify DNA encoding the entire recA gene from $X$. bovienii $\mathrm{T} 228$

PCR amplification of a $363 \mathrm{bp}$ internal fragment of the recA gene of $X$. bovienii was accomplished using degenerate oligonucleotide primers based on 27 aligned RecA amino acid sequences. The DNA sequence of the coding strand primer $\left[5^{\prime}-\right.$ TT(TCA)AT(TC)GA(TCAG)GC(TC)GA(AG)CA(TC)GC$\left.3^{\prime}\right]$ has a 192-fold degeneracy and the complementary strand primer $\left[5^{\prime}\right.$-CC(AT)CC(AT)G(GT)(AT)GT(ATG)GT(CT)TC(ATCG)GG-3'] has a 384-fold degeneracy. The PCR reaction mixture consisted of: $1 \times$ PCR buffer, $2.0 \mathrm{mM} \mathrm{MgCl}_{2}$, $0.2 \mathrm{mM}$ of each dNTP (Pharmacia Biotech), formamide $(1.5 \%, \mathrm{v} / \mathrm{v}), 125 \mathrm{pmol}$ of each primer and 1.25 units of AmpliTaq Gold II Taq polymerase (Perkin Elmer). Approximately 100 ng template chromosomal DNA from X. bovienii was used per reaction tube. The amplification cycle consisted of an initial $10 \mathrm{~min}$ at $95^{\circ} \mathrm{C}, 30$ cycles of $1 \mathrm{~min}$ at $95^{\circ} \mathrm{C}, 2 \mathrm{~min}$ at $55^{\circ} \mathrm{C}$ and $3 \mathrm{~min}$ at $72{ }^{\circ} \mathrm{C}$, followed by a final $3 \mathrm{~min}$ extension at $72{ }^{\circ} \mathrm{C}$. The PCR product was cloned into pGEM$\mathrm{T}$ Easy Vector System (Promega) and the resulting plasmid designated pCT300. DNA sequence analysis was used to confirm that pCT300 contained an insert containing DNA with homology to other recA sequences.

Inverse PCR was then used to amplify DNA flanking the internal recA fragment on the $X$. bovienii chromosome. Chromosomal DNA was digested to completion with DraI, and the fragments circularized with T4 DNA ligase. Circularized fragments containing the internal recA region were linearized by digestion with $\mathrm{NdeI}$. This enzyme has a single recognition site within the internal recA fragment cloned as an insert in pCT300. Primers complementary to the $5^{\prime}$ and $3^{\prime}$ ends of the internal recA fragment (5'-CACAGCAGGTTATCAATATC-3' and 5'-TTATCAACCAGATCCGTATG-3') were then used to amplify DNA containing the $5^{\prime}$ and 3 ' flanking DNA. The PCR reaction mixture consisted of: $1 \times$ PCR buffer, $2.5 \mathrm{mM} \mathrm{MgCl}_{2}, 2.0 \mathrm{mM}$ of each dNTP, $50 \mathrm{pmol}$ each primer, $100 \mathrm{ng}$ template DNA and 1.25 units AmpliTaq Gold II Taq DNA polymerase. The amplification 
Table 1. Bacterial strains and plasmids used in this study

\begin{tabular}{|c|c|c|}
\hline Strain or plasmid & Relevant properties & Source or reference \\
\hline \multicolumn{3}{|l|}{ E. coli } \\
\hline $\mathrm{DH} 5 \alpha$ & Cloning strain & BRL \\
\hline DK1 & $\Delta(\operatorname{sr} 1-r e c A)$ & Casadaban \& Cohen (1980) \\
\hline JC14604 & $\mathrm{F}^{-} l a c^{-} h s d R \Delta(\operatorname{sr} 1-r e c A) 306$ & Clark (1973) \\
\hline SM10( $\lambda$ pir) & $\begin{array}{l}\text { thi-1 thr leu tonA lacY supE } \\
\text { recA::RP4-2-Tc:: } \mathrm{Mu}, \mathrm{Km}^{\mathrm{r}} \text {, } \lambda \text { pir }\end{array}$ & Miller \& Mekalanos (1988) \\
\hline SY327(גpir) & $\Delta($ lac-pro $) \arg E(\mathrm{Am})$ rif nalA rec $A 56$ & Donnenberg \& Kaper (1991) \\
\hline Sarcina lutea & & IMVS, Adelaide, South Australia \\
\hline \multicolumn{3}{|l|}{ X. bovienii } \\
\hline T228 & $\mathrm{Ap}^{\mathrm{r}} \mathrm{Sm}^{\mathrm{r}}, \mathrm{P} 1$ and $\mathrm{P} 2$ variants & $\begin{array}{l}\text { R. J. Akhurst, CSIRO } \\
\text { Entomology, Canberra, Australia }\end{array}$ \\
\hline ХB001 & $\mathrm{T} 228 \operatorname{rec} A:: \mathrm{Km}, \mathrm{Km}^{\mathrm{r}}$ & This study \\
\hline XB002 & XB001 containing pCT303, $\mathrm{Tc}^{\mathrm{r}}$ & This study \\
\hline \multicolumn{3}{|l|}{ Plasmids } \\
\hline pBSL15 & Source of $\mathrm{Km}^{\mathrm{r}}$ cassette & Alexegev (1995) \\
\hline pCVD442 & Suicide vector, $\mathrm{Ap}^{\mathrm{r}}$, sacB mobRP4 & Donnenberg \& Kaper (1991) \\
\hline $\begin{array}{l}\text { pGEM-T, } \\
\text { pGEMT Easy }\end{array}$ & PCR cloning vector, $\mathrm{Ap}^{\mathrm{r}}$ & Promega \\
\hline pSUP203 & Mobilizable vector, $\mathrm{Ap}^{\mathrm{r}} \mathrm{Cm}^{\mathrm{r}} \mathrm{Tc}^{\mathrm{r}}$ & Simon et al. (1983) \\
\hline pWKS130 & Cloning vector, $\mathrm{Ap}^{\mathrm{r}}$ & Wang \& Kushner (1991) \\
\hline pCT300 & $\begin{array}{l}\text { pGEM-T Easy with a } 363 \text { bp PCR } \\
\text { product insert containg part of the } \\
\text { X. bovienii recA gene }\end{array}$ & This study \\
\hline рСТ301 & $\begin{array}{l}\text { pGEM-T with a } 962 \text { bp PCR product } \\
\text { insert containing part of X. bovienii } \\
\text { recA gene }\end{array}$ & This study \\
\hline pCT301.1 & $\begin{array}{l}\text { pCT301 with a } \mathrm{Km}^{\mathrm{r}} \text { cassette inserted } \\
\text { into the unique } E \text { coRI site }\end{array}$ & This study \\
\hline pCT301.2 & $\begin{array}{l}\text { pCVD } 442 \text { with the } 962 \mathrm{bp} \mathrm{recA} \\
\text { fragment containing a } \mathrm{Km}^{\mathrm{r}} \text { cassette, } \\
\text { removed from pCT301.1 as an } \\
\text { SphI-SalI fragment }\end{array}$ & This study \\
\hline pCT302 & $\begin{array}{l}\text { pGEM-T with the } r e c A \text { gene cloned as } \\
\text { a } 2064 \text { bp PCR product }\end{array}$ & This study \\
\hline рСТ302.1 & $\begin{array}{l}\text { pWKS130 containing the } \operatorname{rec} A \text { gene, } \\
\text { cloned as a NotI fragment, in the } \\
\text { same orientation as the lac } Z \\
\text { promoter }\end{array}$ & This study \\
\hline рСТ302.2 & $\begin{array}{l}\text { pWKS130 containing the } \operatorname{rec} A \text { gene, } \\
\text { cloned as a NotI fragment, in the } \\
\text { opposite orientation to the lac } Z \\
\text { promoter }\end{array}$ & This study \\
\hline pCT303 & $\begin{array}{l}\text { pSUP203 containing the } r e c A \text { gene } \\
\text { cloned as a Pst } \mathrm{I}-\text { Not } \mathrm{I} \text { fragment }\end{array}$ & This study \\
\hline
\end{tabular}

cycle consisted of an initial $10 \mathrm{~min}$ at $95^{\circ} \mathrm{C}$, then 30 cycles of $1 \mathrm{~min}$ at $95^{\circ} \mathrm{C}, 1 \mathrm{~min}$ at $55^{\circ} \mathrm{C}$ and $5 \mathrm{~min}$ at $72^{\circ} \mathrm{C}$, followed by a final 7 min extension at $72^{\circ} \mathrm{C}$. The $\sim 1.5 \mathrm{kbp}$ PCR fragment produced was subjected to sequence analysis and this was used to extend the known recA DNA sequence.

Additional DNA sequence data $5^{\prime}$ to the known $r e c A$ sequence were obtained by plasmid-assisted PCR rescue based on a method described by Luo \& Cella (1994). Briefly, X. bovienii chromosomal DNA was digested with EcoRI and BamHI, followed by ligation to EcoRI- and BamHI-digested pBR322.
This preparation of DNA was then used in a PCR using oligonucleotide primers specific for the tetracycline-resistance gene of pBR322 (5'-TCTTCCCCATCGGTGATG-3') and known $5^{\prime}$ recA DNA sequence (5'-CAGACGCATGATAGAACC-3') for X. bovienii. The PCR reaction mixture consisted of: $1 \times$ PCR buffer, $2.5 \mathrm{mM} \mathrm{MgCl}_{2}$, 50 pmol of each primer, $2.0 \mathrm{mM}$ of each dNTP, $100 \mathrm{ng}$ template DNA and 1.25 units TaqBead Hot Start Polymerase (Promega). The mixture was overlaid with mineral oil. The amplification cycle consisted of an initial $2 \mathrm{~min}$ at $94^{\circ} \mathrm{C}$, then 30 cycles of $1 \mathrm{~min}$ at $94^{\circ} \mathrm{C}, 30 \mathrm{~s}$ 
at $55^{\circ} \mathrm{C}$ and $3.5 \mathrm{~min}$ at $72{ }^{\circ} \mathrm{C}$, followed by a final $3.5 \mathrm{~min}$ extension at $72{ }^{\circ} \mathrm{C}$. The PCR product was subjected to sequence analysis.

Compilation of the sequence data obtained allowed design of oligonucleotide primers which would allow amplification of the complete DNA sequence of the recA gene from X. bovienii. The entire $X$. bovienii recA gene, plus flanking DNA, was cloned as a PCR fragment prepared using oligonucleotide primers P227 (5'-CAGCTTAGTATTGAACTTGG-3') and P2293 (5'-AGTGAACTGCTTGGTACTAT-3') as follows. The PCR reaction mixture consisted of: $1 \times$ PCR buffer, $2.5 \mathrm{mM} \mathrm{MgCl}, 50 \mathrm{pmol}$ of each primer, $2.0 \mathrm{mM}$ of each dNTP, $100 \mathrm{ng}$ chromosomal DNA and 1.25 units TaqBead Hot Start Polymerase. The mixture was overlaid with mineral oil. The amplification cycle consisted of an initial incubation for $2 \mathrm{~min}$ at $94^{\circ} \mathrm{C}, 30$ cycles of $1 \mathrm{~min}$ at $94^{\circ} \mathrm{C}, 30 \mathrm{~s}$ at $55^{\circ} \mathrm{C}$ and $2.5 \mathrm{~min}$ at $72{ }^{\circ} \mathrm{C}$, followed by a final $2.5 \mathrm{~min}$ incubation at $72^{\circ} \mathrm{C}$. PCR products were cloned using the pGEM-T Vector System (Promega) and the resulting construct designated pCT302.

A 962 bp DNA fragment internal to recA, used as a probe for Southern hybridization analysis and construction of an insertion mutant, was amplified using the oligonucleotide primers RecAF (5'-AGGTTCTATCATGCGTCTGG-3') and RecAR (5'-TCCAGAGACTGCACTACTGA-3'). PCR was carried out as described above and the 962 bp product cloned into pGEM-T. The resulting construct was designated pCT301. The 962 bp PCR product cloned in pCT301 was prepared for use as a DNA probe by incorporation of digoxigenin-labelled dNTPs (Boehringer Mannheim) in place of normal dNTPs in a PCR reaction using primers RecAF and RecAR. Southern hybridization was performed as previously described (Southern, 1975) and modified (Reed, 1990). Digoxigenin-labelled probe DNA was detected colorimetrically as recommended by the manufacturer (Boehringer Mannheim).

High-efficiency electrotransformation of $E$. coli strains. Electrotransformation was performed using an E. coli Gene Pulser (Bio-Rad) as described by the manufacturer.

Recombination proficiency assay. A recombination proficiency assay was used to demonstrate the ability of the cloned recA gene to facilitate recombination. E. coli strain JC14604 (Clark, 1973) is a recA mutant containing a tandem duplication of the lac $Z$ gene, with each copy of the gene containing a different missense mutation. In the presence of RecA a recombination event can produce a functional copy of lacZ. Cells in which this event occurs can give rise to colonies capable of producing Lac papillae on MacConkey agar.

Plasmids pCT302, pCT302.1 and pCT302.2 were used to transform E. coli strain JC14604. Plasmid pCT302.1 contained the recA gene cloned into pWKS130 as a NotI fragment in the same orientation as the lacZ promoter. Plasmid pCT302.2 was identical to pCT302.1 except that recA was in the opposite orientation. Control transformations with pGEM-T and pWKS130 were also performed. All transformants were plated on MacConkey agar, incubated at $37^{\circ} \mathrm{C}$ for $48 \mathrm{~h}$ and examined for presence of Lac papillae.

Bacterial conjugation. Filter matings were carried out with modification as previously described (Achtman et al., 1978). Donor and recipient strains were grown overnight with gentle shaking (to avoid damage to the sex pili of the donor) in NB containing appropriate antibiotics. Cells were collected by centrifugation, gently washed and resuspended in fresh NB. These broth suspensions were mixed to achieve a donor: recipient ratio of $1: 10$, and $100 \mu \mathrm{l}$ was then plated on a sterile nitrocellulose filter laid on the surface of a pre-warmed NA plate. Plates were incubated at $28^{\circ} \mathrm{C}$ overnight; the filter was then removed and placed in $1 \mathrm{ml} \mathrm{NB}$ to recover the cells. A $100 \mu \mathrm{l}$ sample of the suspension was plated onto the appropriate selective media.

Construction of a recA mutant. The suicide delivery vector required for allelic-exchange mutagenesis was constructed as follows. An EcoRI fragment encoding a kanamycin-resistance gene cartridge from pBSL15 was inserted into EcoRI-digested pCT301. This insertion resulted in a $\operatorname{rec} A:: \mathrm{Km}$ construct which was composed of 706 and 256 bp of Xenorhabdus recA DNA flanking the $5^{\prime}$ and $3^{\prime}$ ends of the kanamycin-resistance gene cartridge respectively. The resulting plasmid (pCT301.1) was then digested with $S p h I$ and SalI to isolate the $\operatorname{rec} A:: \mathrm{Km}$ construct, and this was ligated to $S p h \mathrm{I} / \mathrm{SalI}$-digested vector pCVD442 to produce pCT301.2. E. coli SY327( $\lambda$ pir) carrying pCT301.2 was selected by growth on NA supplemented with Ap and Km. Plasmid pCT301.2 was then used to transform E. coli SM10( $\lambda$ pir). Conjugal transfer of pCT301.2 between this transformant and P1 X. bovienii was then performed. Cointegrates were selected by their resistance to Ap, $\mathrm{Km}$ and $\mathrm{Sm}$, and resolved by plating on $\mathrm{NaCl}$-free NA containing $6 \%$ $(\mathrm{w} / \mathrm{v})$ sucrose (Blomfield et al., 1991). A single sucroseresistant colony containing a putative $\operatorname{rec} A: \mathrm{Km}$ mutation was selected and designated $X$. bovienii XB001. Allelic replacement of recA with the recA:: Km insertion mutation was confirmed by PCR and Southern hybridization analysis.

Construction of a complemented $X$. bovienii recA insertion mutant. The recA gene from pCT302 was isolated as a Pst I-Not I fragment and subcloned into the conjugative vector pSUP203. This construct, designated pCT303, was tested in an E. coli JC14604 background to confirm that a functional copy of the recA gene was present. Plasmid pCT303 was then transferred from E. coli SM10 ( $\lambda$ pir) into X. bovienii XB001 by conjugation. Exconjugants were selected on NA containing $\mathrm{Sm}$ and Tc. A single isolate, designated X. bovienii XB002, was selected for use in complementation analysis. P2 variants of XB002 were obtained by serial broth culture and selection on BTB agar.

UV sensitivity studies. Bacteria to be tested were grown overnight at the correct temperature, with appropriate antibiotic selection. Cultures were washed twice in saline before being resuspended in saline to an $\mathrm{OD}_{600}$ of 1.0 (LKB Ultraspec Plus Spectrophotometer, Pharmacia). A $4 \mathrm{~mm}$ diameter loop was used to streak a standard inoculum of each culture over a distance of $5 \mathrm{~cm}$ on NA plates containing appropriate antibiotics. Inoculated plates were allowed to dry for $15 \mathrm{~min}$ before exposure to a UV source for 0-50 s. UV-treated plates were immediately incubated in the dark. The extent of bacterial growth on each plate was compared to that on control plates which had not been exposed to UV light.

Maintenance of Galleria mellonella larvae. G. mellonella eggs were obtained from Dr Kerry Davis (Department of Crop Protection, Waite Campus, University of Adelaide). Eggs were hatched on growth medium mixture consisting of wheatgerm $(100 \mathrm{~g})$, Heinz High Protein Baby Cereal (125 g), honey $(100 \mathrm{ml}), 100 \%$ glycerol $(100 \mathrm{ml})$, Torula yeast $(1.0 \mathrm{~g})$, Nipagen (Sigma) $(0 \cdot 15 \mathrm{~g})$ and the contents of five $500 \mathrm{mg}$ multivitamin capsules (Cenovis). Larval cultures were incubated at $28{ }^{\circ} \mathrm{C}$ for 5-6 weeks. Sixth-instar larvae were used for all experiments described.

$\mathrm{LD}_{50}$ of $X$. bovienii for G. mellonella. P1 and P2 cultures of $X$. bovienii T228 and XB001 were incubated for $12 \mathrm{~h}$ at $28^{\circ} \mathrm{C}$ with shaking. Bacterial cells were harvested by centrifugation 
(4000 $g$ for $5 \mathrm{~min}$ ), resuspended in PBS and kept on ice. Serial dilutions of these suspensions were used to infect larvae. Viable counts of bacteria per dose were estimated by triplicate plating of $100 \mu \mathrm{l}$ volumes of appropriate dilutions on NA.

Sixth-instar larvae were infected with bacteria as follows. Larvae weighing 120-160 mg were selected and surface sterilized with $70 \%(\mathrm{v} / \mathrm{v})$ ethanol prior to infection. Using a Hamilton syringe, each larva in a group of 10 was then injected with $10 \mu \mathrm{l}$ of either a bacterial suspension or PBS. Treated larvae were incubated at $28^{\circ} \mathrm{C}$ for up to $72 \mathrm{~h}$. At regular intervals, each treatment group was examined and the number of dead or moribund larvae recorded. Estimates of the $\mathrm{LD}_{50}$ of $X$. bovienii strains for G. mellonella larvae were then determined (Reed \& Muench, 1938).

\section{RESULTS}

\section{Cloning and sequence analysis of the $X$. bovienii T228 recA gene}

Preliminary experiments enabled us to identify recAassociated DNA sequences which permitted amplification of a $2064 \mathrm{bp}$ fragment using the oligonucleotide primer pair P227 and P2293. The PCR product was cloned into pGEM-T and the resulting plasmid designated pCT302. The X. bovienii recA gene, plus flanking DNA, contained in the 2064 bp insert in pCT302 was sequenced (GenBank accession U87924) and compared with the recA sequence of $X$. nematophilus AN6 (GenBank accession AF127333).

The entire $X$. bovienii recA gene, including regulatory sequences, is contained in a $1676 \mathrm{bp} \mathrm{DraI} \mathrm{fragment.} \mathrm{The}$ recA genes of both $X$. bovienii and X. nematophilus consist of an ORF of $1077 \mathrm{bp}$ (including the stop codon) which is preceded by a putative ribosome-binding site (-AAGGAG-). Putative promoter sequences were found $76 \mathrm{bp}$ and $47 \mathrm{bp}$ upstream from the initiation codons of the recA gene from $X$. bovienii (TTGATG--16 bp-TATAAT) and $X$. nematophilus (TTTATC--17 bp-TTCATT) respectively. Putative stem-loop structures were found 35 and 21 bp downstream from the stop codons of the $X$. bovienii and $X$. nematophilus recA genes respectively. Both recA genes encode two putative
ATP-binding domains located at positions $178-234 \mathrm{bp}$ (inclusive) and 769-843 bp (inclusive) relative to the start of the ORF. Analysis of the translated sequence data identified the critical arginine and glycine residues required for homologous recombination (Müller \& Kokjohn, 1990), encoded in both genes at 181-183 bp (inclusive) and 898-900 bp (inclusive) respectively.

The recA genes from $X$. bovienii and X. nematophilus were $85 \%$ identical at the nucleotide level and $95 \%$ identical at the amino acid level. Analysis of the $X$. bovienii recA gene revealed extensive identity at the amino acid level to the recA genes of Erwinia carotovora (92\% identity), Proteus mirabilis (87\% identity), Serratia marcescens (88\% identity) and Yersinia pestis (91\% identity). Furthermore, the LexA binding site region in both $X$. bovienii and $X$. nematophilus is almost identical to that of the E. coli recA gene (Fig. 1).

\section{Phylogenetic studies of recA from Xenorhabdus spp.}

Fig. 2 shows the phylogenetic relatedness of the fulllength RecA amino acid sequence of $X$. bovienii and $X$. nematophilus and those of 44 other bacteria. This phenogram showed that the two complete Xenorhabdus spp. RecA sequences were most closely related to one another, and furthermore grouped together with RecA sequences derived from other members of the family Enterobacteriaceae.

\section{Assessment of $X$. bovienii recA function in $E$. coli}

A recombination proficiency assay was used to determine whether E. coli JC14604 carrying the X. bovienii recA gene on plasmid pCT302 could promote recombination. When grown on MacConkey agar, this strain did not express Lac papillae indicative of recombination events leading to formation of a functional LacZ protein. Two possible explanations for this observation were that the X. bovienii gene was not efficiently expressed in an E. coli host, or that the copy number of the expression plasmid was too high, which in turn resulted in gene dosage effects. The former was unlikely since other
X. bovienii T228 recA

E. $\operatorname{coli}$ recA

S. marcescens recA
cttgatgCTGtatgattataCAGtataatt . . 64 . . AGGAgtaaacATGgctaa |||||||||||||||||||||||||||||| ||||||||||||||||||| cttgatgCTGtatgattataCAGtataatc . .64 . . AGGAgtaaacATGgctaa ||||||||||||| ||||||||||| |||||||| |||||| cttgataCTGtatgagcataCAGtataatt. . 44. . AGGAgtaaaaATGgctat ||||||||||||||||||||||||||$|\quad|||||||||||||||||$ cttgataCTGtatgaccataCAGtataatt. . 65 . . AGGAgcaaaaAggctat SOS Box RBS Met

Fig. 1. Upstream regulatory sequences of the recA genes from $X$. bovienii T228, X. nematophilus AN6, $E$. coli and $S$. marcescens. Conserved bases from the consensus SOS box (LexA binding site) are highlighted (CTG and CAG), along with the ribosome-binding site (AGGA) and start codon (ATG). 


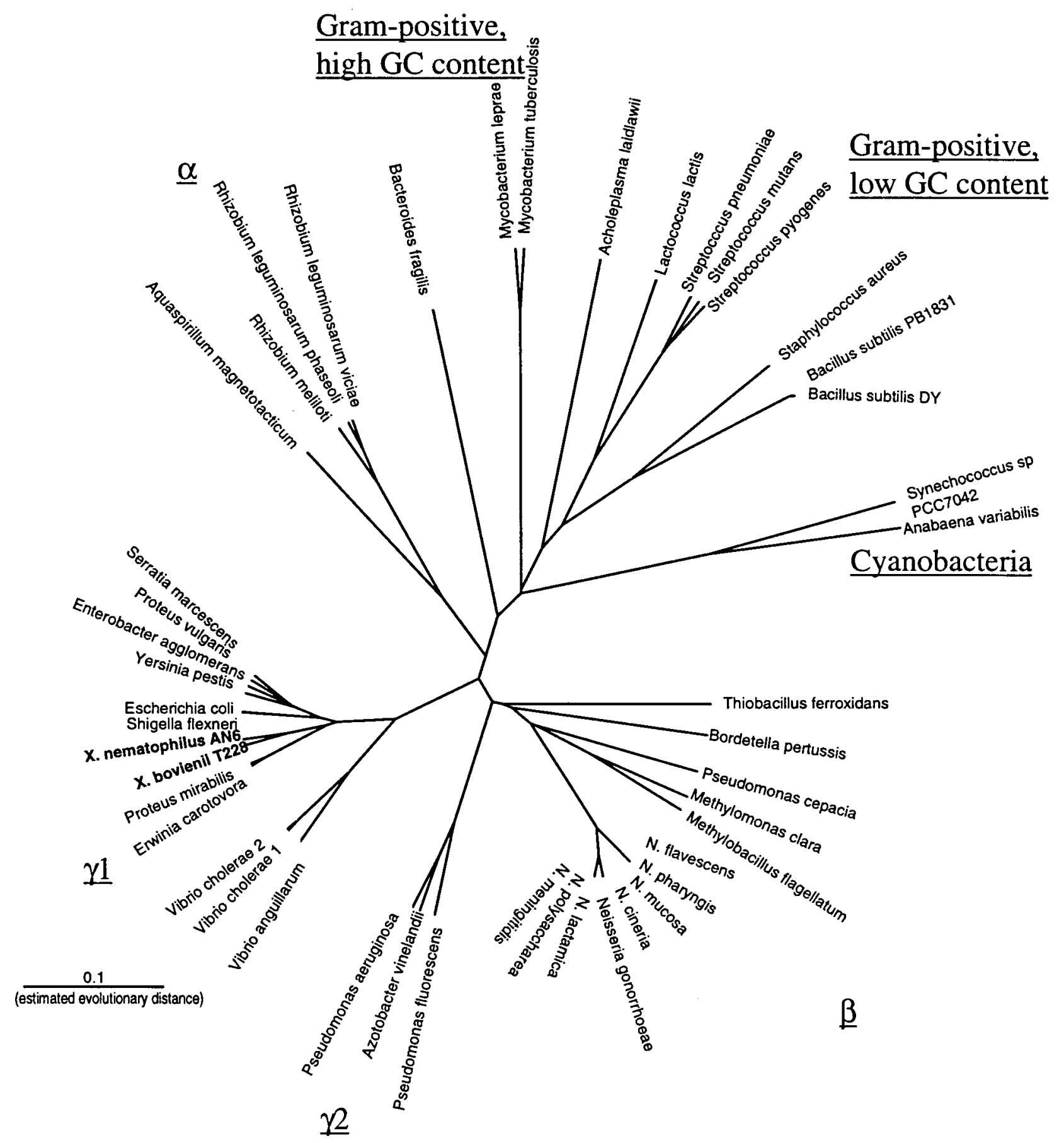

Fig. 2. Unrooted radial tree produced using distance methods to compare the RecA amino acid sequence of $X$. bovienii T228 and X. nematophilus AN6 to the RecA sequences of $44 \mathrm{Gram}$-positive and Gram-negative bacteria. No outgroup was selected.

Xenorhabdus genes [for example fliC and fliD for X. nematophilus flagella synthesis (Givaudan et al., 1996)], have been successfully expressed in E. coli. To investigate the effect of copy number on recA expression, the recA gene from pCT302 was subcloned as a NotI fragment into the low-copy-number vector $\mathrm{pWKS} 130$. Clones pCT302.1 and pCT302.2, with recA in the same or opposite orientation as the lac $Z$ promoter of pWKS130 respectively, were then used to transform $E$. coli JC14604. When plated on MacConkey agar, both clones produced colonies with Lac papillae and hence expressed functional RecA. These data implicated plasmid copy number as a reason for the failure of pCT302 to promote recombination in E. coli JC14604. 


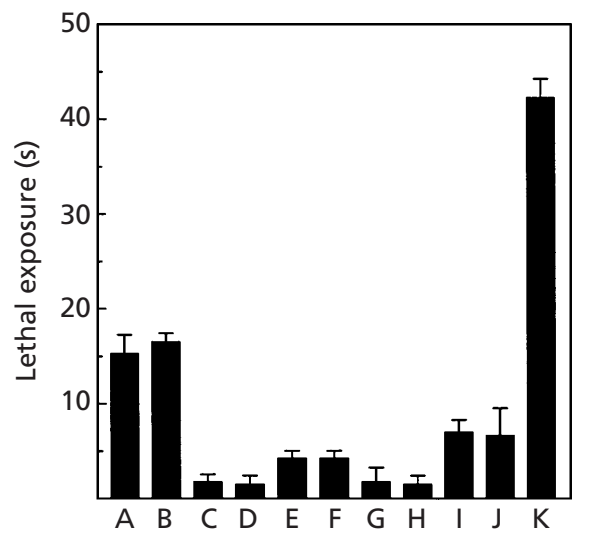

Fig. 3. Comparison of resistance to UV killing by strains of $X$. bovienii and E. coli. Resistance to UV is measured as exposure time required to completely inhibit growth of an inoculum of bacteria on a nutrient agar plate. Results shown are the means of four independent observations per experimental group. Error bars represent $95 \%$ confidence intervals about the mean. A, X. bovienii T228 P1; B, X. bovienii T228 P2; C, XB001 P1; D, XB001 P2; $E$ ， XB001(pCT303) P1; F, XB001(рСТ303) P2; G, XB001(pSUP203) P1; H, XB001(pSUP203) P2; I, E. coli DK1; J, $E$. coli DK1(pSUP203); K, E. coli DK1(pCT303).

Further confirmation of a functional RecA was obtained by examining the UV sensitivity of the E. coli recA deletant strain, DK1, after transformation with plasmid pCT303. DK1(pCT303) demonstrated increased ability to resist UV-mediated killing when compared to DK1 alone, or DK1 carrying the vector pSUP203. After $8 \mathrm{~s}$ exposure, no surviving colonies of either DK1 or DK1(pSUP203) were detected, whereas DK1(pCT303) was able to survive up to $44 \mathrm{~s}$ exposure (Fig. 3).

\section{Characterization of an $X$. bovienii recA insertion mutant}

A X. bovienii recA insertion mutant (XB001) was constructed by allelic exchange. PCR analysis using primers RecAF and RecAR confirmed an insertion in the recA gene. A 962 bp fragment was amplified from DNA isolated from the wild-type parent, whilst a $2.1 \mathrm{~kb}$ fragment was amplified from XB001 DNA. This corresponded to the insertion of a $1.2 \mathrm{~kb}$ kanamycin-resistance cassette in recA (data not shown). Furthermore, Southern hybridization analysis of DraI-digested chromosomal DNA showed that a 962 bp recA-specific DNA probe (derived from pCT301) hybridized with $1.6 \mathrm{~kb}$ and $2.8 \mathrm{~kb}$ fragments for the wild-type and mutant strains respectively (Fig. 4). These data indicated XB001 contained a recA::Km insertion mutation which was not the result of co-integrate formation.

No difference in the UV sensitivity of P1 and P2 strains of $X$. bovienii was detected (Fig. 3), although these strains were clearly more sensitive to UV exposure than the complemented E. coli strain DK1(pCT303). P1 and $\mathrm{P} 2$ variants of the $X$. bovienii recA insertion mutant $\mathrm{XB} 001$ were very sensitive to UV and were unable to survive even brief $(<3 \mathrm{~s})$ UV exposure. However,

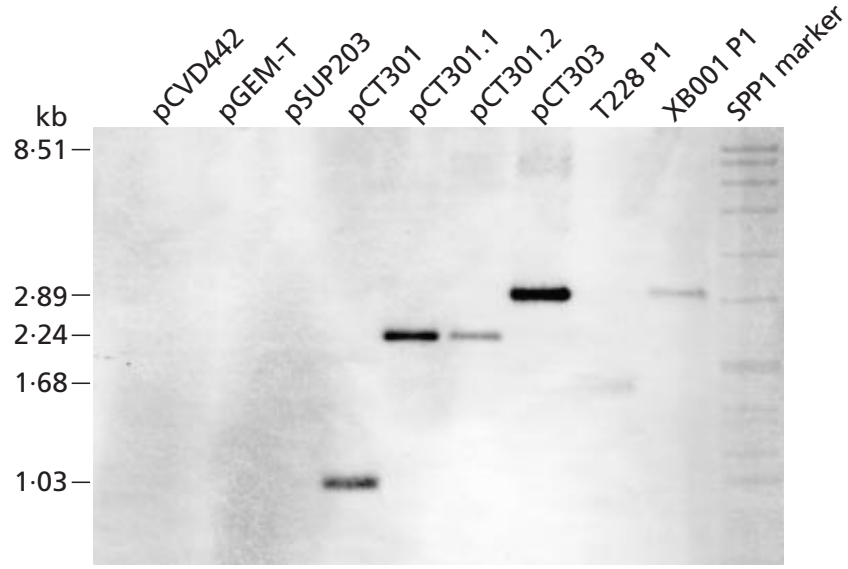

Fig. 4. Southern hybridization analysis of plasmid and chromosomal DNA prepared from $X$. bovienii strains T228 and the recA insertion mutant XB001. Plasmids pCVD442, pGEM-T, pSUP203 and PCT303 were digested with Dral; plasmids pCT301, pCT301.1 and pCT301.2 were digested with Sphl and Sall; chromosomal DNA from T228 and XB001 was digested with Dral. The filters were probed with a digoxigenin-labelled $962 \mathrm{bp}$ internal recA fragment PCR amplified from pCT301. The sizes of DNA fragments hybridizing with the probe DNA are shown. SPP1 marker is Bacillus subtilis phage SPP1 DNA digested with EcoRI.

complemented P1 and P2 variants (which harboured pCT303) demonstrated partial restoration of resistance to UV-mediated killing, while transformants harbouring the vector pSUP203 alone remained UV sensitive.

\section{Expression of phase-dependent phenotypic characteristics by the recA insertion mutant and the recA-complemented strain}

No differences were detected betwen the wild-type $X$. bovienii strain T228, the recA insertion mutant XB001 and the recA-complemented strain $\mathrm{XB} 001$ (pCT303) in the expression of phospholipase $\mathrm{C}$, haemolysin or protease activity. In all three strains, P1 variants were positive and $\mathrm{P} 2$ variants negative for all these characters (results not shown). Similarly, antibiotic production and Congo Red binding ability were unaffected by mutations in recA. When P1 forms of the recA mutant were subcultured onto BTB agar, P2 forms were readily isolated. Furthermore, PCR and restriction endonuclease analysis of $\mathrm{P} 1$ and $\mathrm{P} 2$ variants of wild-type and recA mutants were unable to identify any alteration or rearrangement in recA (data not shown).

\section{Virulence of recA mutants for G. mellonella}

In order to determine whether $\operatorname{rec} A$ plays a role in the pathogenicity of X. bovienii for susceptible insect larvae, $\mathrm{LD}_{50}$ analysis was used to compare wild-type P1 and P2 bacteria and the $X$. bovienii recA insertion mutant, XB001. Sixth instar larvae were infected with known doses of X. bovienii T228 or XB001. Control groups of larvae were injected with PBS. The viability of the bacterial suspensions used did not change significantly 


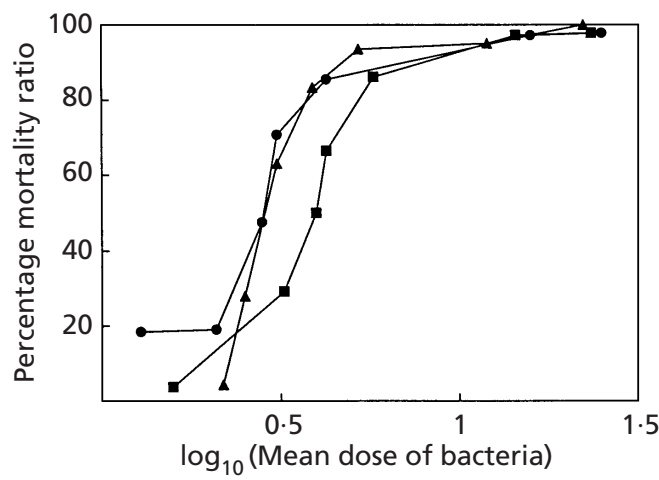

Fig. 5. Selected dose-response curves for $G$. mellonella larvae infected with P1 and P2 $X$. bovienii wild-type bacteria or the rec $A$ insertion mutant (XB001). $\boldsymbol{A}, X$. bovienii T228 P1;,$X$. bovienii T228 P2; $\mathbf{\square}, X$. bovienii ХB001 P1

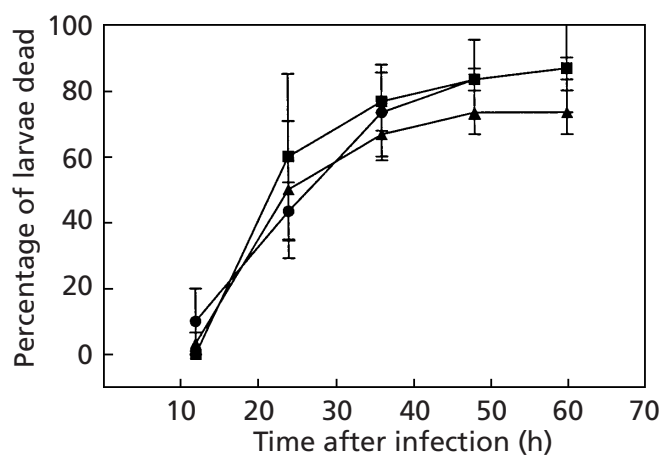

Fig. 6. Proportion of larvae dying over a $60 \mathrm{~h}$ period following infection with doses of bacteria approximating that of the calculated $\mathrm{LD}_{50}$ for P1 $X$. bovienii T228 ( $\sim 4$ cells per larva). Larvae were infected with P1 and P2 $X$. bovienii wild-type bacteria or the recA insertion mutant (XB001). Error bars represent the standard error about the mean. $\boldsymbol{\Lambda}, X$. bovienii T228 P1; , X. bovienii T228 P2; $\mathbf{\square}$, X. bovienii XB001 P1.

over the time required to infect groups of larvae. Treated larvae were incubated at $28{ }^{\circ} \mathrm{C}$ for up to $72 \mathrm{~h}$ and the numbers of dead or moribund larvae recorded at regular time intervals.

All strains killed larvae irrespective of the dose applied. Doses greater than 5 bacteria per larva consistently killed all larvae within 24-36 h, whereas lower doses killed only a proportion of infected larvae. No deaths were recorded for control groups of larvae. $\mathrm{LD}_{50}$ values were determined directly from plots of percentage dosage mortality vs mean dose of bacteria (Reed \& Muench, 1938). The mean $\mathrm{LD}_{50}$ values obtained from three independent experiments using P1 and P2 wildtype strains and the $\operatorname{rec} A$ mutant were $3 \cdot 1 \pm 0 \cdot 05$, $3.4 \pm 1.5$ and $2.7 \pm 0.9$ respectively. One-way analysis of variance indicated these were not significantly different $(P>0.05)$. These estimates of the $\mathrm{LD}_{50}$ are similar to those reported elsewhere (Pinyon et al., 1996). Typical plots of percentage mortality ratio vs dose of bacteria were also very similar (Fig. 5). Furthermore, when doses of bacteria approximating the calculated $\operatorname{LD}_{50}(\sim 4$ cells per larva) were used, the proportion of larvae dying over a $60 \mathrm{~h}$ period was not significantly different for the wildtype strain and the recA mutant $(P>0.05$, analysis of variance; Fig. 6).

\section{DISCUSSION}

In this study we used PCR-based techniques to clone and sequence the recA gene from $X$. bovienii T228. The translated sequence was $95 \%$ identical to that of the related species, $X$. nematophilus AN6, and showed considerable similarity to RecA proteins from Gramnegative bacteria, in particular Erwinia carotovora, Proteus mirabilis, Serratia marcescens and Yersinia pestis. We constructed an evolutionary tree relating Xenorhabdus RecA peptide sequences to those of 44 other RecA proteins. This tree was similar to those constructed previously (Eisen, 1995) and supported the position of Xenorhabdus spp. within the family Enterobacteriaceae of the $\gamma 1$ Proteobacteria.

UV sensitivity, complementation analysis and recombination proficiency assays were used to demonstrate expression of a functional $X$. bovienii RecA protein from plasmids in RecA-deficient E. coli backgrounds. However, expression was apparently dependent on plasmid vector copy number. RecA protein instability due to expression from high-copy-number plasmid vectors has been observed previously (Fyfe \& Davies, 1990; Stroeher et al., 1994).

Construction of a chromosomal recA mutation in $X$. bovienii was achieved by allelic exchange of a $\operatorname{rec} A:: \mathrm{Km}$ insertion mutation from a pCVD442-based suicide delivery plasmid. Loss of RecA function by X. bovienii XB001 was established using UV sensitivity studies. Since a functional relationship exists between homologous recombination and the repair of DNA damage, mutations in the $\operatorname{rec} A$ gene sensitize cells to killing by UV light. Although no difference in the UV sensitivity of P1 and P2 wild-type X. bovienii strains was noted, the recA insertion mutant XB001 had significantly reduced ability to repair DNA lesions caused by exposure to UV radiation. Furthermore, resistance to UV-induced damage of this mutant could not be restored to wild-type levels by complementation with a functional copy of recA from plasmid pCT303, even though introduction of pCT303 into E. coli DK1 (which has a deletion of the recA gene) completely restored UV resistance.

Previous in vitro work has shown that the singlestranded DNA-dependent ATPase activity of RecA is a property of the tetrameric form of the protein (Ogawa et al., 1978). Thus ATPase activity is required for the in vitro recombination functions of purified RecA (Radding, 1982; Weinstock et al., 1979), although this is not the case for the proteolytic activity of RecA involved in SOS induction (Phizicky \& Roberts, 1981). ATP binding is also required for formation of RecA tetramers and filamentous aggregates of the RecA protein (Ogawa et al., 1978). When RecA1 missense protein and wildtype RecA protein of E. coli form mixed tetramers in the 
presence of ATP, a dramatic reduction in ATPase activity is observed (Ogawa et al., 1978). Phenotypically, the recA1 mutation, Gly-160 to Asp-160, is indistinguishable from a recA deletion (Kowalczykowski et al., 1994). Therefore the extent of the reduction of ATPase activity is dependent on the ratio of the two polypeptides. In vivo, the recombination activity of wild-type RecA protein is also significantly reduced in the presence of a non-functional RecA1 polypeptide. This phenomenon is known as negative complementation and has been well documented for cases such as the lacZ gene (Müller-Hill et al., 1968), and the capR gene (Charette et al., 1982), where the active form of the protein is a tetramer.

Formation of mixed tetramers of RecA may explain the reduced ability of pCT303 to complement the recA:: Km insertion mutation present in XB001. Mixtures containing truncated proteins consituting up to $79 \%$ of the wild-type protein have been shown to promote strong negative complementation (Yarranton \& Sedgwick, 1982). Since the recA:: Km mutation in XB002 has the potential to express $72 \%$ of the wild-type protein (starting at the $\mathrm{N}$-terminus), this peptide has the potential to facilitate negative complementation in the presence of wild-type RecA (the C-terminal end of this putative truncated 265 amino acid protein is predicted to comprise proline, glycine, isoleucine and arginine derived from the kanamycin-resistance cassette). This hypothesis is supported by fact that the truncated RecA protein encoded by the recA:: Km mutation would not include the ATP-binding site containing a tyrosine residue necessary for co-protease activity and recombination (Cotteril et al., 1982; Knight \& McEntee, 1986). Thus co-protease activity and recombination potential should be either reduced or abolished in strain XB002.

Interestingly, wild-type, $\operatorname{rec} A$ and complemented $\operatorname{rec} A$ strains of $X$. bovienii were identical in terms of expression of known phase-dependent characteristics. Furthermore, P1 variants of the $X$. bovienii recA insertion mutant were able to convert to $\mathrm{P} 2$ forms on extended serial subculture. When these results are taken together with Southern hybridization analyses which showed no obvious large rearrangements in DNA isolated from P1 and P2 forms (Akhurst \& Boemare, 1990), it is very unlikely that recA plays a role in phase variation or regulation of phase-dependent characteristics of Xenorhabdus spp. This conclusion was further supported by larval infection studies, which showed that the recA insertion mutant XB001, was able to kill larvae as well as P1 and P2 forms of the wild-type derivative.

Finally, the construction of recombination deficient mutants is a commonly used approach which aids genetic analysis of virulence factors and other aspects of bacterial physiology. Results from this study will allow progress in molecular analysis of the basis for pathogenesis of Xenorhabdus spp. for susceptible insect larvae as well as other phenotypic characteristics. RecAdeficient mutants not only facilitate genetic complemen- tation analyses, but also increase the stability of recombinant plasmids and retention of foreign DNA.

\section{ACKNOWLEDGEMENTS}

This work was completed with the aid of an Australian Research Council Small Grant. We thank Mr Mark Webster for technical help and Dr Renato Morona for helpful discussion.

\section{REFERENCES}

Achtman, M., Schwuchow, S., Helmuth, R., Morelli, G. \& Manning, P. A. (1978). Cell-cell interactions in conjugating Escherichia coli: con-mutants and stabilization of mating aggregates. Proc Natl Acad Sci US A 76, 4837-4841.

Akhurst, R. J. (1982a). Antibiotic activity of Xenorhabdus spp., bacteria symbiotically associated with insect pathogenic nematodes of the families Heterorhabditidae and Steinernematidae. J Gen Microbiol 128, 3061-3065.

Akhurst, R. J. (1982b). A Xenorhabdus sp. (Eubacteriales: Enterobacteriaceae) symbiotically associated with Steinernema kraussei. Rev Nematol 5, 277-280.

Akhurst, R. J. (1993). Bacterial symbionts of entomopathogenic nematodes - the power behind the throne. In Nematodes and the biological control of insect pests, pp. 127-135. Edited by R. Bedding, R. J. Akhurst \& H. Kaya. Melbourne: CSIRO Publications.

Akhurst, R. J. \& Boemare, N. E. (1990). Biology and taxonomy of Xenorhabdus. In Entomopathogenic Nematodes in Biological Control, pp. 75-90. Edited by R. Gaugler \& H. K. Kaya. Boca Raton, FL: CRC Press.

Akhurst, R. J. \& Dunphy, G. B. (1993). Tripartite interactions between symbiotically associated entomopathogenic bacteria, nematodes, and their insect hosts. In Parasites and Pathogens of Insects, vol. 2, pp. 1-23. Edited by N. Beckage, S. Thompson \& B. Federici. New York: Academic Press.

Alexegev, M. F. (1995). Three kanamycin resistance gene cassettes with different polylinkers. BioTechniques 18, 52-53.

Altschul, S. F., Gish, W., Miller, W., Myers, E. W. \& Lipman, D. J. (1990). Basic local alignment search tool. J Mol Biol 215, 403-410.

Ball, T. K., Wasmuth, C. R., Braunagel, S. C. \& Benedik, M. J. (1990). Expression of Serratia marcescens extracellular proteins requires recA. J Bacteriol 172, 342-349.

Bewsey, K. E., Johnson, M. E. \& Huff, P. (1991). Rapid isolation and purification of DNA from agarose gels: the phenol-freezefracture method. BioTechniques 10, 724-725.

Blomfield, I. C., Vaughn, V., Rest, R. F. \& Eisenstein, B. I. (1991). Allelic exchange in Escherichia coli using the Bacillus subtilis sacB gene and temperature-sensitive pSC101 replicon. Mol Microbiol 5, 1447-1457.

Boemare, N. \& Akhurst, R. J. (1988). Biochemical and physiological characterization of colony form variants in Xenorhabdus spp. (Enterobacteriaceae). J Gen Microbiol 134, 751-761.

Boemare, N., Thaler, J. O. \& Lanois, A. (1997). Simple bacteriological tests for phenotypic characterization of Xenorhabdus and Photorhabdus phase variants. Symbiosis 22, 167-175.

Casadaban, M. J. \& Cohen, S. M. (1980). Analysis of gene control signals by DNA fusion and cloning in Escherichia coli. J Mol Biol 179, 179-208.

Charette, M. F., Henderson, G. W., Kezdy, F. J. \& Markovitz, A. (1982). Molecular mechanism for dominance of a mutant allele of an ATP-dependent protease. J Mol Biol 162, 503-510. 
Clark, A. J. (1973). Recombination deficient mutants of E. coli and other bacteria. Annu Rev Genet 7, 67-86.

Cotteril, S. M., Satterthwait, A. C. \& Fersht, A. R. (1982). RecA protein from Escherichia coli. A very rapid and simple purification procedure: binding of adenose $5^{\prime}$-triphosphate and adenosine $5^{\prime}$ diphosphate by the homogenous protein. Biochemistry 21, 4332-4337.

Couche, G. A. \& Gregson, R. P. (1987). Protein inclusions produced by the entomopathogenic bacterium Xenorhabdus nematophilus subsp. nematophilus. J Bacteriol 169, 5279-5288.

Couche, G. A., Lehbach, P. R., Forage, R. G., Cooney, D. R., Smith, G. C. \& Gregson, R.P. (1987). Occurrence of intracellular inclusions and plasmids in Xenorhabdus spp. J Gen Microbiol 133, 967-973.

Donnenberg, M. S. \& Kaper, J. B. (1991). Construction of an eae deletion mutant of enteropathogenic Escherichia coli using a positive-selection suicide vector. Infect Immun 59, 4310-4317.

Eisen, J. A. (1995). The RecA protein as a model molecule for molecular systematic studies of bacteria - comparison of trees of recAs and $16 \mathrm{~S}$ rRNAs from the same species. J Mol Evol 41, 1105-1123.

Forst, S. \& Nealson, K. (1996). Molecular biology of the symbiotic pathogenic bacteria Xenorhabdus spp. and Photorhabdus spp. Microbiol Rev 60, 21-43.

Fyfe, J. A. M. \& Davies, J. K. (1990). Nucleotide sequence and expression in Escherichia coli of the recA gene of Neisseria gonorrhoeae. Gene 93, 151-156.

Givaudan, A., Lanois, A. \& Boemare, N. (1996). Cloning and nucleotide sequence of a flagellin encoding genetic locus from Xenorhabdus nematophilus: phase variation leads to differential transcription of two flagellar genes (fliCD). Gene 183, 243-253.

Knight, K. L. \& McEntee, K. (1986). Nucleotide binding by a $24-$ residue peptide from the RecA protein of Escherichia coli. Proc Natl Acad Sci U S A 83, 9289-9293.

Koomey, M., Gotschlich, E. C., Robbins, K., Bergstrom, S. \& Swanson, J. (1987). Effects of recA mutations on pilus antigenic variation and phase transitions in Neisseria gonorrhoeae. Genetics 117, 391-398.

Kowalczykowski, S. C., Dixon, D. A., Eggleston, A. K., Lauder, S. D. \& Rehrauer, W. M. (1994). Biochemistry of homologous recombination in Escherichia coli. Microbiol Rev 58, 401-465.

Luo, N. \& Cella, R. (1994). A reliable amplification technique with single-sided specificity for the isolation of $5^{\prime}$ gene regulating regions. Gene 140, 59-62.

Maniatis, T., Fritsch, E. F. \& Sambrook, J. (1982). Molecular Cloning: a Laboratory Manual. Cold Spring Harbor, NY : Cold Spring Harbor Laboratory.

Manning, P. A., Heuzenroeder, M. W., Yeadon, J., Leavesley, D. I., Reeves, P. R. \& Rowley, D. (1986). Molecular cloning and expression in Escherichia coli $\mathrm{K}-12$ of the $\mathrm{O}$ antigens of the Inaba and Ogawa serotypes of the Vibrio cholera O1 lipopolysaccharides and their potential for vaccine development. Infect Immun 53, 272-277.

Miller, V. L. \& Mekalanos, J. J. (1988). A novel suicide vector and its use in construction of insertion mutations: osmoregulation of outer membrane proteins and virulence determinants in Vibrio cholerae requires toxR. J Bacteriol 170, 2575-2583.

Müller, R. V. \& Kokjohn, T. A. (1990). General microbiology of $\operatorname{rec} A$ : environmental and evolutionary significance. Annu Rev Microbiol 44, 365-391.
Müller-Hill, B., Crapo, L. \& Gilbert, W. (1968). Mutants that make more lac repressor. Proc Natl Acad Sci US A 59, 1259-1264.

Nealson, K. H., Schmidt, T. M. \& Bleakley, B. (1990). Physiology and biochemistry of Xenorhabdus. In Entomopathogenic Nematodes in Biological Control, pp. 271-284. Edited by R. Gaugler \& H. Kaya. Boca Raton, FL: CRC Press.

Ogawa, T., H. Wabiko, T. Tsurimoto, T. Horii, H. Masukata \& Ogawa, H. (1978). Characterisitics of purified RecA protein and the regulation of its synthesis in vivo. Cold Spring Harbor Symp Quant Biol 43, 909-915.

Phizicky, E. M. \& Roberts, J. W. (1981). Induction of SOS functions: regulation of proteolytic activity of E. coli RecA protein by interaction with DNA and nucleoside triphosphate. Cell 25, 259-267.

Pinyon, R. A., Linedale, E. C., Webster, M. A. \& Thomas, C. J. (1996). Tn5-Induced Xenorhabdus bovienii Lecithinase Mutants Demonstrate Reduced Virulence For Galleria mellonella Larvae. J Appl Bacteriol 80, 411-417.

Poinar, G. O. \& Thomas, G. M. (1966). Significance of Achromobacter nematophilus Poinar and Thomas (Achromobacteraceae: Eubacteriales) in the development of the nematode, DD136 (Neoaplectana sp.: Steinernematidae). Parasitology 56, 385-390.

Radding, C. M. (1982). Homologous pairing and strand exchange in genetic recombination. Annu Rev Genet 16, 405-437.

Reed, K. (1990). Basic blotting - a quick fix. Today's Life Sci 2, 52-60.

Reed, L. J. \& Muench, H. (1938). A simple method of estimating fifty percentage end-points. Am J Hyg 27, 493-497.

Simon, R., Priefer, U. \& Puhler, A. (1983). A broad host range mobilization system for in vivo genetic engineering: transposon mutagenesis in gram negative bacteria. Biotechnology 1, 784-791.

Southern, E. M. (1975). Detection of specific sequence among DNA fragments separated by gel electrophoresis. J Mol Biol 98, 503-517.

Stroeher, U. H., Lech, A. J. \& Manning, P. A. (1994). Gene sequence of rec $\mathrm{A}^{+}$and construction of recA mutants of Vibrio cholerae. Mol Gen Genet 244, 295-302.

Thompson, J. D., Higgins, D. G. \& Gibson, T. J. (1994). CLUSTAL w : improving the sensitivity of progressive multiple sequence alignment through sequence weighting position gap penalties and weight matrix choice. Nucleic Acids Res 22, 4673-4680.

Wang, R. F. \& Kushner, S. R. (1991). Construction of versatile lowcopy-number vectors for cloning, sequencing and gene expression in Escherichia coli. Gene 100, 195-199.

Weinstock, G. M., McEntee, K. \& Lehman, I. R. (1979). ATPdependent renaturation of DNA catalyzed by the RecA protein of Escherichia coli. Proc Natl Acad Sci US A 76, 126-130.

Yarranton, G. T. \& Sedgwick, S. G. (1982). Cloned truncated recA genes in E. coli. II. Effects of truncated gene products on in vivo RecA ${ }^{+}$protein activity. Mol Gen Genet 185, 99-104.

Zagaglia, C., Casalino, M., Colonna, B., Conti, C., Calconi, A. \& Nicoletti, M. (1991). Virulence plasmids of enteroinvasive Escherichia coli and Shigella flexneri integrate into a specific site on the host chromosome: integration greatly reduces expression of plasmid-carried virulence genes. Infect Immun 59, 792-799.

Received 3 April 2000; revised 21 July 2000; accepted 8 August 2000. 